Mеталлофиз. новейшие технол. / Metallofiz. Noveishie Tekhnol. (C) 2014 ИМФ (Институт металлофизики 2014 , т. 36, № 3, сс. 317-327

Оттиски доступны непосредственно от издателя

им. Г. В. Курдюмова НАН Украины)

Фотокопирование разрешено только

Напечатано в Украине.

в соответствии с лицензией

PACS numbers: 52.77.Fv, 61.66.Dk, 62.20.Qp, 81.20.Vj, 81.40.Pq

\title{
Wear Behaviour of Crankshaft Journals Filled by Submerged Arc Welding
}

\author{
A. A. Öztürk, B. Gülenç, A. Durgutlu, and N. Kahraman* \\ Gazi University, Technology Faculty, \\ Teknikokullar \\ 06500 Ankara, Turkey \\ "Karabük University, Technology Faculty, \\ Balıklar Kayası Campus, \\ 78050 Karabük, Turkey
}

In this study, wear behaviour of crankshaft journals filled by a submerged arc welding with different welding wires and powders is investigated. Hardness and microstructure variations in the submerged arc welding are examined. In addition, the amount of weight loss in abrasion samples of filling dry and lubrication ambience is measured under $40 \mathrm{~N}$ loads. It is observed that the amount of abrasion decreased with the increase of hardness at a certain point. Thin wire structure is provided for better abrasion resistance, and abrasion decreases with lubrication.

В работе исследован режим износа цапф коленчатого вала, обработанных дуговой сваркой под флюсом с различными сварочными проволоками и порошками. Изучены вариации твёрдости и микроструктуры при дуговой сварке под флюсом. Кроме того, была измерена величина потери веса в образцах, подвергнутых истиранию в сухих и смазочных средах при нагрузках в 40 Н. Наблюдалось уменьшение величины истирания с увеличением твёрдости до определённого предела. Было обеспечено использование тонкой проволоки для лучшего сопротивления истиранию, а истирание уменьшалось при смазке.

В роботі досліджено режим спрацювання цапф колінчастого валу, оброблених дуговим зварюванням під флюсом з різними зварювальними дротами і порошками. Досліджено варіації твердості та мікроструктури при дуговому зварюванні під флюсом. Крім цього, було виміряно величину втрати ваги в зразках, підданих стиранню в сухих і змащувальних середовищах при навантаженнях у 40 Н. Спостерігалося зменшення величини стирання зі збільшенням твердості до певної границі. Було забезпечено використання тонкого дроту для кращого опору стиранню, а стирання зменшувалося при змащуванні. 
Key words: crankshaft journal, submerged arc welding, filling, wear.

(Received October 3, 2013)

\section{INTRODUCTION}

The most severe degradation modes that crankshaft bearings have to face are friction and wear. Surface damages generated by the sliding contact with bearings limit the life of the shafts and therefore reduce their durability and reliability. Wear of machinery components is one of the most common problems in engineering applications [1]. Hardfacing is a surface treatment to improve surface properties of metals, in which welding metal having excellent resistance to wear and oxidation is deposited onto a surface of a substrate [2]. The weld deposition of hardfacing alloys is commonly employed in industry to increase the service life of components subject to abrasive wear [3]. Hardfacing is a technique used to enhance surface properties of a metallic component, as a specially designed alloy is surface welded in order to achieve specific wear properties [4]. Several welding techniques such as oxyacetylene gas welding (OAW), gas metal arc welding (GMAW), shielded metal arc welding (SMAW), and submerged arc welding (SAW) can be used for hardfacing [5].

Submerged arc cladding has been used in modern industries, especially for the heavy section steels and for a large structure surfaces needing to be modified [6]. In high-productivity submerged-arc surfacing, the dilution of the filler material with the parent metal can be effectively reduced by using alloyed agglomerated fluxes and/or cored wires $[7,8]$. In submerged-arc welding, there are several ways of increasing welding efficiency. The followings are known: multiple-wire welding, multiple-electrode welding, hot wire welding, cold wire welding, and welding with metal-powder addition [9]. The submerged arc welding process is commonly used due to its easy applicability, high current density and its ability to deposit a large amount of weld metal using more than one wire at the same time, especially in restoration of worn parts, which is of great importance to manufacturers [10-13]. It can be available in automatic or semi-automatic mode and has good reliability [14-16].

In this study, in order to investigate the effect of submerged arc welding on the wear behaviour of worn crankshaft bearings, wear tests are performed. For this purpose, various weld wires and fluxes are used.

\section{EXPERIMENTAL STUDY}

In this study, abrasion behaviour of submerged arc welding is investi- 
gated in different wire and powder filling for welding onto crankshafts in automotive industry. In the experiments, a Mercedes OM 355 lorry crankshaft was used. The composition of used material is presented in Table 1. In the experiments, the wires with diameter of $1.2 \mathrm{~mm}$ and different chemical composition of welding powders added to metal are used. The chemical composition of welding wires used in welding and the properties of the powders are presented in Table 2 and Table 3 , respectively.

In the experimental study, submerged arc welding machine, Peterson Machine, is used. This machine is equipped with an automatic special construction-welding device for the crankshaft journals welding. In the machine, the variation of voltage and current can be read, and welding speed is controlled easily. Within the given parameter range, the crankshaft journals have to be welded by five welds from left to right. During the welding, the temperature should not exceed $250^{\circ} \mathrm{C}$ between the passes (Table 4 ).

The welding region of the crankshaft journals (seven main journals and three pin journals) was cut through the vertical pivot axis by the

TABLE 1. The chemical composition of base metal.

\begin{tabular}{c|c|c|c|c|c|c|c|c|c|c}
\hline Element & $\mathrm{C}$ & $\mathrm{Si}$ & $\mathrm{Mn}$ & $\mathrm{P}$ & $\mathrm{S}$ & $\mathrm{Cr}$ & $\mathrm{Mo}$ & $\mathrm{Ni}$ & $\mathrm{Al}$ & $\mathrm{Co}$ \\
\hline \% Ratio & 0.420 & 0.273 & 0.773 & 0.017 & 0.024 & 1.06 & 0.036 & 0.146 & 0.018 & 0.021 \\
\hline
\end{tabular}

TABLE 2. The chemical compositions of added metal used in the experiments.

\begin{tabular}{c|c|c|c}
\hline \multirow{2}{*}{ Add wire } & \multicolumn{3}{|c}{ Compositions } \\
\cline { 2 - 4 } & $\mathrm{C}$ & $\mathrm{Si}$ & $\mathrm{Mn}$ \\
\hline SG2 & 0.08 & 0.85 & 1.45 \\
SG3 & $0.06-0.13$ & $0.80-1.15$ & $1.60-1.85$ \\
\hline
\end{tabular}

TABLE 3. The chemical compositions of welding powders used in the experiments.

\begin{tabular}{cc}
\hline Powder used for welding & Composition \\
\hline OP 139 (Oerlikon) & $20 \% \mathrm{SiO}_{2}+\mathrm{TiO}_{2}, 25 \% \mathrm{CaO}+\mathrm{MgO}$, \\
& $35 \% \mathrm{Al}_{2} \mathrm{O}_{3}+\mathrm{MnO}_{3}, 15 \% \mathrm{CaF}_{2}$ \\
OP 176 (Oerlikon) & $44 \% \mathrm{SiO}_{2}+\mathrm{TiO}_{2}, 23 \% \mathrm{CaO}+\mathrm{MgO}$ \\
Linkolin H 560 & $24 \% \mathrm{Al}_{2} \mathrm{O}_{3}+\mathrm{MnO}_{3}, 7 \% \mathrm{CaF}_{2}$ \\
$75 \%$ Linde 55 + 25\% Lincoln 760 & (no given) \\
\hline
\end{tabular}


TABLE 4. The welding parameters used for welding.

\begin{tabular}{|c|c|c|c|c|c|}
\hline $\begin{array}{c}\text { Welding } \\
\text { region }\end{array}$ & \begin{tabular}{|l|} 
Code of \\
Sample
\end{tabular} & $\begin{array}{l}\text { Add } \\
\text { wire }\end{array}$ & Powder of weld & $\begin{array}{c}\text { Current of } \\
\text { weld, A }\end{array}$ & $\begin{array}{l}\text { Speed of weld- } \\
\text { ing, } \mathrm{mm} / \mathrm{min}\end{array}$ \\
\hline $\begin{array}{l}\text { First main } \\
\text { journal }\end{array}$ & $1 \mathrm{~A}$ & SG2 & $\begin{array}{c}75 \% \text { linde } 55+25 \% \text { Lin- } \\
\text { coln } 760\end{array}$ & $210 \pm 5$ & 550 \\
\hline $\begin{array}{l}\text { Second main } \\
\text { journal }\end{array}$ & $2 \mathrm{~A}$ & SG3 & $\begin{array}{c}75 \% \text { linde } 55+25 \% \text { Lin- } \\
\text { coln } 760\end{array}$ & $210 \pm 5$ & 550 \\
\hline $\begin{array}{l}\text { Third main } \\
\text { journal }\end{array}$ & $3 \mathrm{~A}$ & SG3 & Oerlikon 139 & $210 \pm 5$ & 550 \\
\hline $\begin{array}{l}\text { Fourth main } \\
\text { journal }\end{array}$ & $4 \mathrm{~A}$ & SG2 & Oerlikon 139 & $210 \pm 5$ & 550 \\
\hline $\begin{array}{l}\text { Fifth main } \\
\text { journal }\end{array}$ & $5 \mathrm{~A}$ & SG3 & Lincoln H560 & $210 \pm 5$ & 550 \\
\hline $\begin{array}{l}\text { Sixth main } \\
\text { journal }\end{array}$ & $6 \mathrm{~A}$ & SG2 & Lincoln H560 & $210 \pm 5$ & 550 \\
\hline $\begin{array}{l}\text { Seventh } \\
\text { main jour- } \\
\text { nal }\end{array}$ & $7 \mathrm{~A}$ & SG3 & Oerlikon 176 & $210 \pm 5$ & 550 \\
\hline $\begin{array}{l}\text { First pin } \\
\text { journal }\end{array}$ & 1B & SG2 & Oerlikon 176 & $180 \pm 5$ & 500 \\
\hline $\begin{array}{l}\text { Second pin } \\
\text { journal }\end{array}$ & $2 \mathrm{~B}$ & SG2 & $\begin{array}{c}50 \% \text { LincoreH } 560+50 \% \\
(75 \text { linde } 55+\% 25 \text { Lin- } \\
\text { coln } 760)\end{array}$ & $180 \pm 5$ & 500 \\
\hline $\begin{array}{l}\text { Third pin } \\
\text { journal }\end{array}$ & 3B & SG3 & $\begin{array}{c}50 \% \text { LincoreH560 }+50 \% \\
(75 \text { linde } 55+\% 25 \text { Lin- } \\
\text { coln } 760)\end{array}$ & $180 \pm 5$ & 500 \\
\hline
\end{tabular}

ribbon saw. The abrasion samples with dimensions $10 \times 10 \times 10 \mathrm{~mm}^{3}$ are prepared (Fig. 1). Four pieces are prepared for the abrasion tests on every journal (totally eight pieces dry and lubricated), totally 80 pieces pattern. The faces of the prepared samples are levelled appropriate to the abrade mechanism.

As shown in Figure 2, the abrasion experiments are performed in abrasion test apparatus. In the experiments, $40 \mathrm{~N}$ loads are applied and abrasion is carried out at the speed of $330 \mathrm{rpm}$ in dry and lubricated conditions. Petrol Office $20 \times 50$ oil is used in lubricated abrasion.

Firstly, the samples are cleaned with alcohol and cellulose thinner for the abrasion experiments and initial weight is scaled on a digital balance with $0.001 \mathrm{~g}$ precision. The abrasion operations are stopped through every $100 \mathrm{~m}$ and weight losses of the samples are measured. The weight loss during the abrasion occurred in sample before the scale operation is stopped and the experiments completed at $1300 \mathrm{~m}$. In 


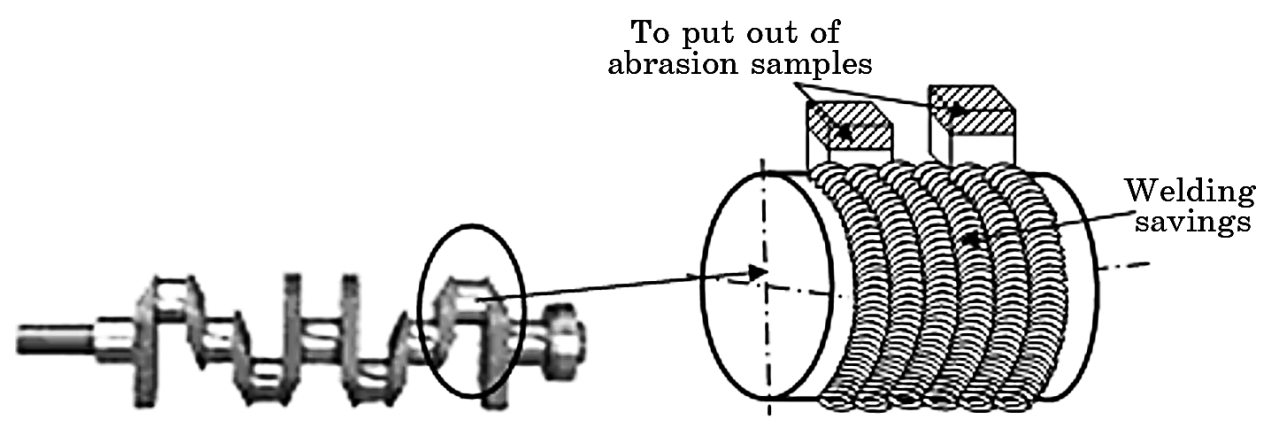

Fig. 1. Filling of the crankshaft journals and preparation for the abrasion samples.

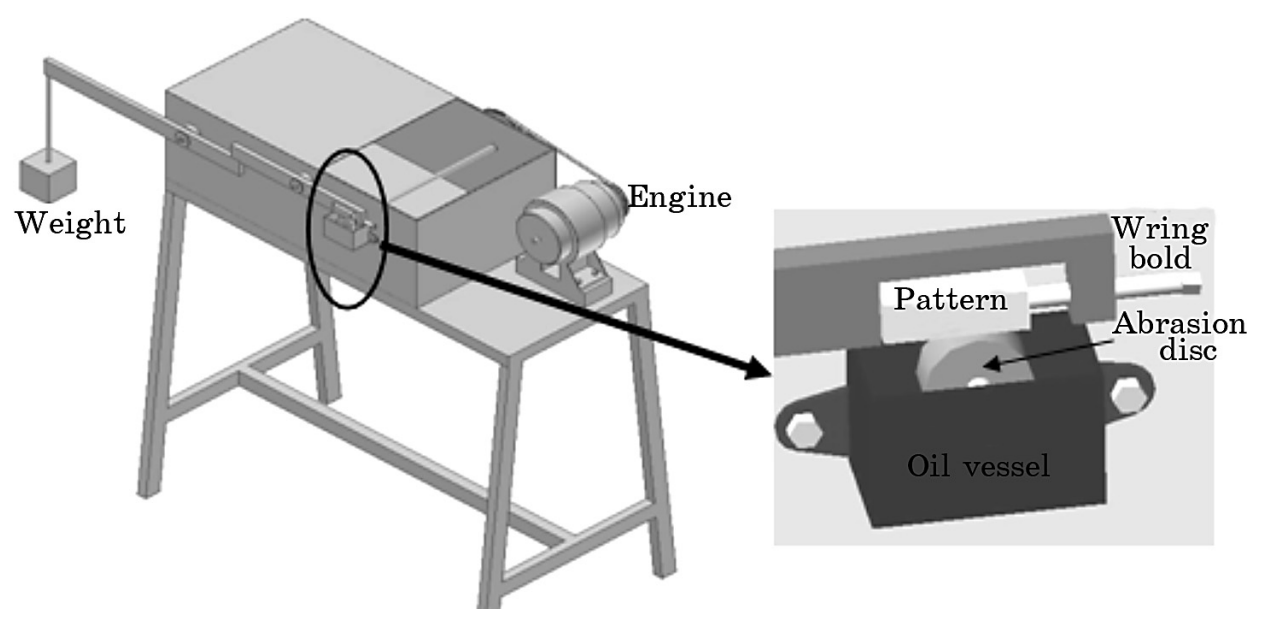

Fig. 2. Abrasion apparatus.

these experiments, $330 \mathrm{rpm}$ and $50 \mathrm{~mm}$ diameter abrasion discs are used for abrasion test. During the abrasion test, the required time is calculated for same distance to every sample using the following equations:

$$
S=\pi d n t, t=Y /(\pi n d),
$$

where $S$-distance $(100 \mathrm{~m}), n$-speed $(330 \mathrm{rpm}), d$-disc diameter $(50 \mathrm{~mm}), t$-time $(\mathrm{s})$, which is equal to

$$
t=100 /(3,14 \cdot 330 \cdot 0,05)=1,93 \min =116 \mathrm{~s} .
$$

The specimens for abrasion, hardness and microstructural examina- 
tion were machined from the welding area with the dimensions of $10 \times 10 \times 10 \mathrm{~mm}^{3}$. The microstructural samples were prepared with the conventional techniques and etched with $2.5 \%$ Nital solution. Microstructure was examined by PRIOR optical microscope. The measurements of welding samples were perform using HRc machine for four regions in welding area such as base metal, partly transformed zone, grain growth zone, and welding zone. As a result, four measurements were made for each zone and average value is reported for each specimen.

\section{RESULTS AND DISCUSSION}

\subsection{Hardness Measurements}

Figure 3 shows the amount of hardness of the crankshaft journals welded with submerged arc method with different wire and powders (pass of weld zone, heat affected zone (grain growth and partly transformed zone) and base metal).

As shown in Fig. 3, hardness values of the heat affected zone (HAZ) and base metal are different. Maximum hardness was measured from the final pass of weld metal, then grain growth zone (in melting border neighbouring influence region), partly transformed zone (from HAZ of the base metal), and base metal showed the lowest hardness. Furthermore, similar hardness values are obtained on the base metal. However, different hardness values are obtained in the welding zone and other regions. In Figure 3, the reason for changing hardness in the welding samples is caused by different composition of additional metal and powder type in welding process. It is known that the welding zone is composed of base metal and added one.

During the welding, the powder is used for protection of the welding region from negative effects of the air. The melted powder causes weld-

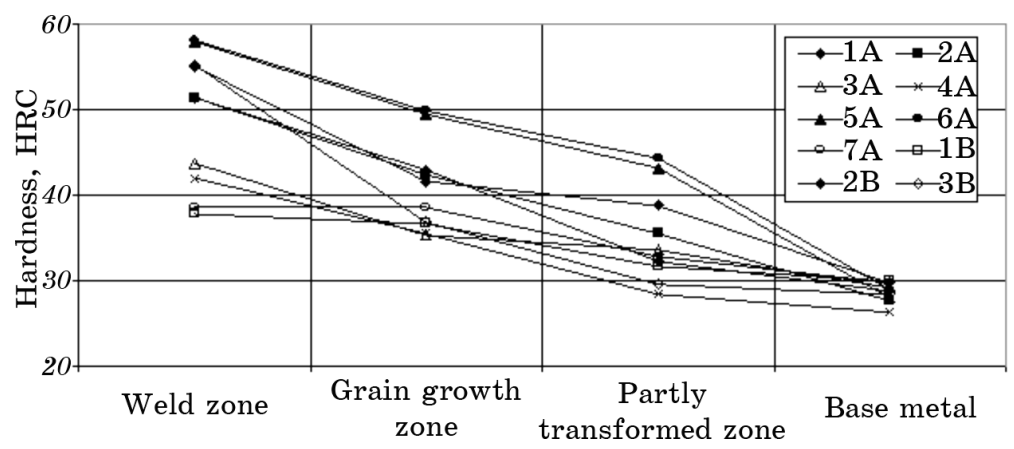

Fig. 3. Hardness values measured in the welding samples. 
ing of alloys and decreases the cooling speed on the welding seam. During the welding, additional metal is sent directly into the welding pool, and then mixtures and welding zone are formed due to high temperature and turbulence of base metal and the additional metal. Under these conditions, welding metal appears during the welding using additional metal and, depending on chemical composition of powder protecting the welding zone, different hardness values are obtained in the work.

As it is seen from Figure 3, used additional metal affects filled samples of the same powder and welding parameters for the hardness of welding zone. Here, it is observed that hardness values of the welding with the filling of SG2 wire are higher than that of SG3 wire filling of the samples. When investigating chemical compositions of two wires, the amount of chemical element in SG3 wire is higher than that of SG2 wire. For this reason, hardness values are higher in the presented samples with SG3 wire filling comparing with the other fillings. As it was reported in the previous works concerning submerged arc welding [10, 17], hardness of welding changes very much with welding wire and composition of powder. The present results are consistent with the previous studies.

\subsection{Abrasion Resistance}

The parameters of submerged arc welding with different wires and powders using filling welding and the amount of abrasion in ambience with dry and lubricated conditions has been taken and illustrated in Fig. 4 and Fig. 5, respectively.

As shown in Figure 4, maximum abrasion resistance is obtained in $2 \mathrm{~A}$ sample (SG3 wire and $75 \%$ linde $+25 \%$ Lincoln 760 powder), then

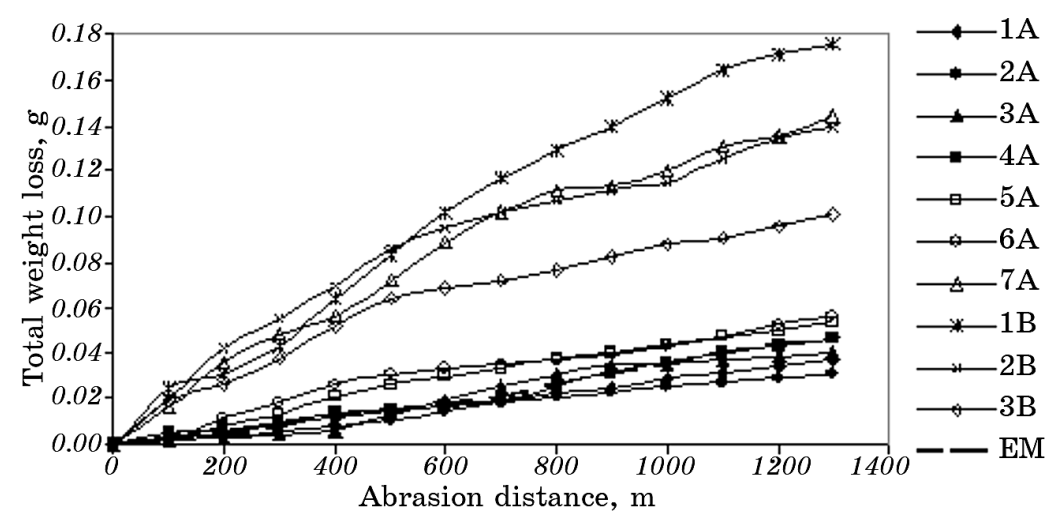

Fig. 4. Dry abrasion relationship between abrasion interval and loss of total weight. 


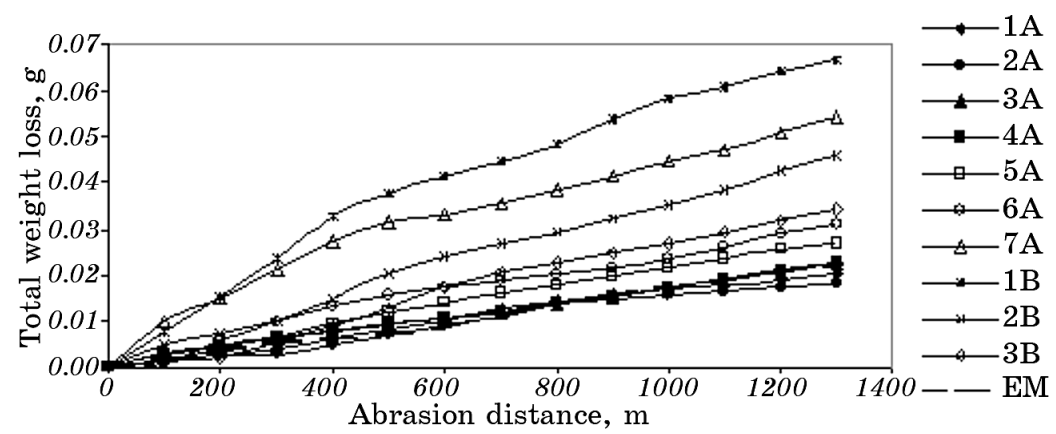

Fig. 5. Lubricated abrasion relationship between abrasion interval and loss of total weight.

in $1 \mathrm{~A}, 3 \mathrm{~A}, 4 \mathrm{~A}, 5 \mathrm{~A}, 6 \mathrm{~A}, 7 \mathrm{~A}$, and finally minimum abrasion resistance in 1B (SG2 wire and Oerlikon 176 powder) sample has been measured. When this order is carefully investigated, abrasion resistance of welding with SG3 wire is higher than that in SG2. This is caused by the presence of higher content of $\mathrm{C}, \mathrm{Si}$, and $\mathrm{Mn}$ elements in SG3 wire. In addition, the total weight loss slowly increases with the increase of abrasion distance in the graph. The reason of the slowness in total weight loss is caused by the work hardening during the abrasion. The presented results are consistent with the earlier works $[10,18]$.

In Figure 5, where the abrasion graph is obtained in lubricated conditions, the abrasion resistance is performed in such an order: $2 \mathrm{~A}, 1 \mathrm{~A}$, $3 \mathrm{~A}, 4 \mathrm{~A}, 5 \mathrm{~A}, 6 \mathrm{~A}, 3 \mathrm{~B}, 2 \mathrm{~B}, 7 \mathrm{~A}$, and $1 \mathrm{~B}$. One of the ways to reduce abra-

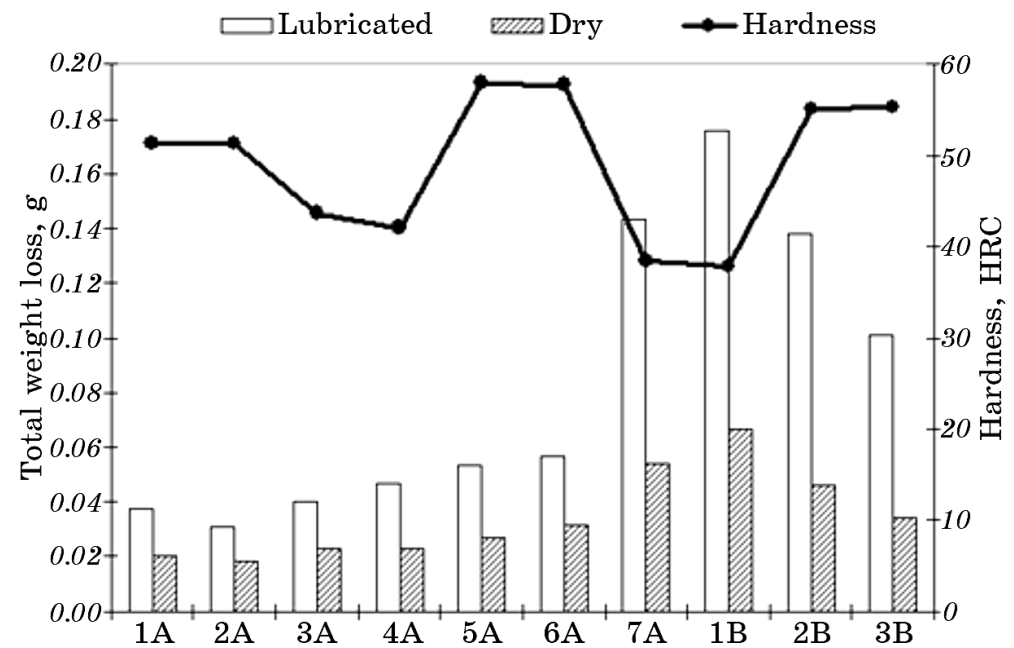

Fig. 6. The hardness results on loss of total weight loss in dry and lubricated conditions. 
sion is forming of oil layer, which creates the friction among the working surfaces.

The comparison of hardness and weight loss is shown in Fig. 6 for welding samples under dry and lubricated conditions. It is seen that the samples $1 \mathrm{~B}$ and $7 \mathrm{~A}$ demonstrate maximum abrasion in weld with the lowest hardness in the present work. However, the maximum hardness values of $6 \mathrm{~A}$ and $5 \mathrm{~A}$ samples are not welds with minimum abrasion.

The samples $2 \mathrm{~A}$ and $1 \mathrm{~A}$ demonstrate minimum abrasion in the current study (Fig. 6). In the experimental works, the value of optimum strength was obtained using these values of the welding parameters. Therefore, high hardness values played a role to increase the abrasion resistance comparing to lower ones in the samples of $1 \mathrm{~B}, 7 \mathrm{~A}, 2 \mathrm{~B}$, and $3 \mathrm{~B}$.

It was reported in the literature [19] that if hardness overpasses the certain level (i.e., optimum hardness), it does not mean that hardness increment gave extra abrasion resistance. Here, it is concluded that the more important issue than the hardness is the chemical composition of additional metal and welding powders.

\subsection{Microstructure Investigation}

Figure 7 shows the optical micrographs obtained from the welded samples. It is seen from Fig. 7, $a$ that microstructure has finer and long shaped grains and their grain type is acicular ferrite. It is known that two-dimensional view of acicular ferrite looks needle-like in optical microscope; therefore, it is called as acicular.

In the microstructure (Fig. $7, b$ ), the solidification of welding metal is realised according to the central line of the welding, and grains are oriented in the direction of the heat flow. The reason for maximum abrasion resistance in the samples $1 \mathrm{~A}$ and $2 \mathrm{~A}$ is their finer, thinner and homogeneous microstructure, and optimum hardness of welding metal and at the same time the higher abrasion resistance of the alloying elements in melting powder.

As it is seen from the microstructure of welding metal (Fig. 7, $c-f$ ), grain dimensions increased and fine and thin shaped structure gradually transformed into the equiaxed grains. Evaluating of microstructure and abrasion test results together, it is observed that abrasion resistance decreases with the increase of grain caused by lower strength of the coarse grains (Figs. 6 and 7).

\section{CONCLUSIONS}

1. In the present study, optimum abrasion resistance is obtained in the 


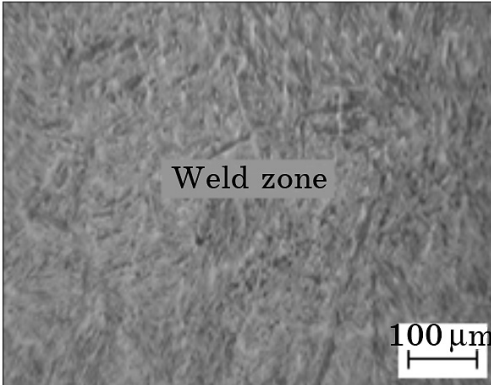

$a$

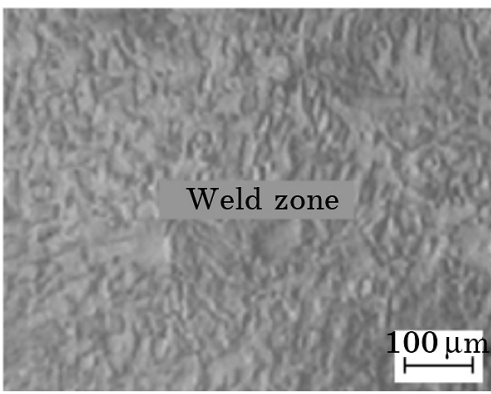

$c$

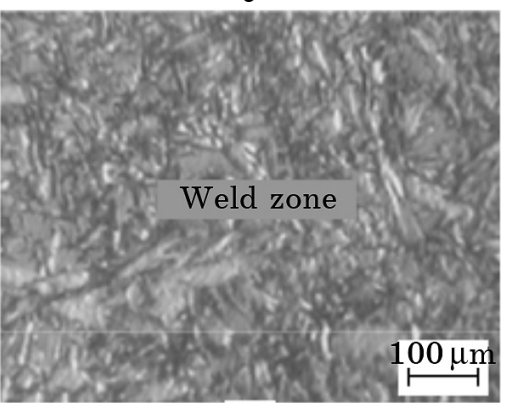

$e$

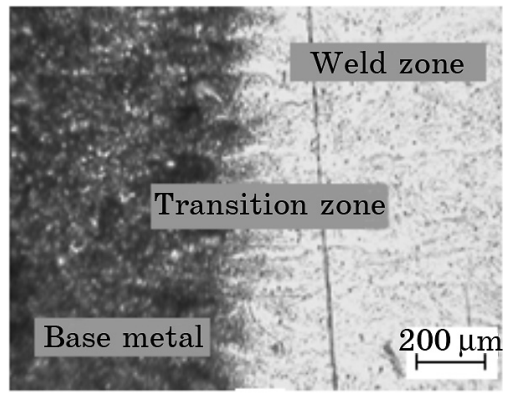

$b$

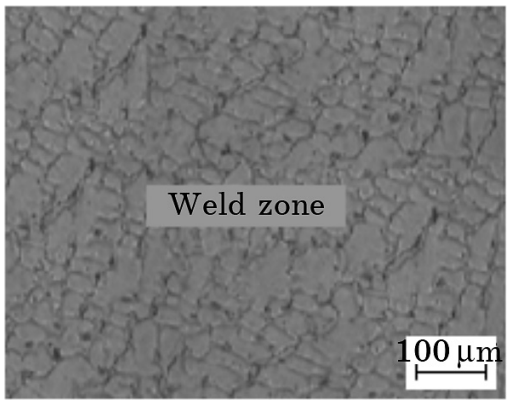

$d$

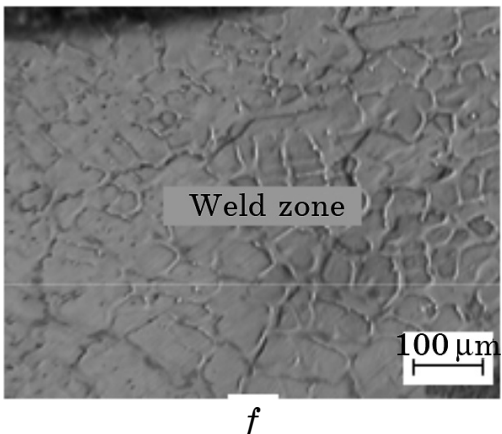

Fig. 7. The micrographs of optic microscope: 1A welding zone (a), 1A welding transition zone $(b)$, $3 \mathrm{~A}$ welding zone $(c), 5 \mathrm{~A}$ welding zone $(d), 1 \mathrm{~B}$ welding zone $(e)$ and 3 B welding zone $(f)$.

powder mixture of $75 \%$ Linde $55+25 \%$ Lincoln 760 and in SG3 wire. 2. Abrasion resistance of fine-grained structure is higher than that of the coarse-grained structure.

3 . The higher carbon, manganese and chromium content in welding wire, the higher abrasion resistance for welding metal is observed.

4. Within the parameters' ranges used in this study, the hardness increment affects the abrasion positively up to an optimum level; however, the higher hardness influenced it negatively.

5. Weight loss for abrasion in lubricated ambience has more ad- 
vantages than that in the dry conditions.

\section{REFERENCES}

1. X. H. Wang, Z. D. Zou, S. Y. Qu, and S. L. Song, J. Mater. Process. Technol., 168: 89 (2005).

2. C. K. Kim, S. Lee, J. Y. Jung, and S. Ahn, Mater. Sci. Eng. A, 349: 1 (2003).

3. J. S. Chatter and T. K. Pal, Wear, 255: 417 (2003).

4. A. S. C. M. D’Oliveira, R. S. C. Paredes, and R. L. C. Santos, J. Mater. Process. Technol., 171: 167 (2006).

5. M. F. Buchely, J. C. Gutierrez, L. M. León, and A. Toro, Wear, 259: 52 (2005).

6. S-P. Lu, O.-Y. Kwon, T.-B. Kim, and K.-H. Kim, J. Mater. Process. Technol., 147: 191 (2004).

7. J. Grum and J. M. Slabe, Appl. Surf. Sci., 208-209: 424 (2003).

8. K. Ferjutz and J. R. Davis, ASM Handbook: Welding, Brazing and Soldering (ASM International: 2000), vol. 6, p. 202.

9. J. Tusek and M. Suban, J. Mater. Process. Technol., 133: 207 (2003).

10. B. Gülenç and N. Kahraman, Materials and Design, 24: 537 (2003).

11. W. Galvery and F. Marlow, Welding Essentials (New York: Industrial Press INC: 2001), p. 212.

12. J. R. Madsen, Welding Fundamentals (New York: American Technical Publishers Inc.: 1999), p. 242.

13. W. M. Robert, Principles of Welding (New York: John Wiley \& Sons, Inc.: 1999), p. 68.

14. V. Gunaraj and N. Murugan, J. Mater. Process. Technol., 95: 246 (1999).

15. G. A. Kennedy, Welding Technology (2 Edition) (California: A Division of Macmillan Publishing Company: 1982), p. 386.

16. A. D. Althouse, C. H. Turnquist, W. A. Bowditch, and K. E. Bowditch, Modern Welding (Tinley Park: The Goodheart-Willcox Company, Inc.: 1993), p. 459.

17. A. Durgutlu, N. Kahraman, and B. Gülenç, The Journal of the Industrial Arts Education Faculty of Gazi University, 10, Iss. 11: 1 (2002) (in Turkish).

18. N. Kiratli, Industrial Lubrication and Tribology, 57, Iss. 4: 150 (2005).

19. C. Çetinkaya, The Determination and Possibility of Improvement of Wear Resistance of Plow Iron (Thesis of Disser. for PhD) (Ankara: Gazi University, Institute of Science and Technology: 1994). 